\title{
Criminal Legal Liability Against Corporate Crimes From the Limited Liability Company Law
}

\author{
Fanema Anugerah $^{1}$, Evita Isretno Israhadi ${ }^{2}$ \\ \{fanemaanugerah@gmail.com ${ }^{1}$, evita_isretno@borobudur.ac.id ${ }^{2}$ \} \\ Universitas Borobudur, Jakarta, Indonesia ${ }^{1,2}$
}

\begin{abstract}
Corporations have a goal in the process of establishment, which then in carrying out corporate action activities are represented by legal subjects, namely people who have responsibilities according to the articles of association of the company in question so that accountability in the company activities of a company is represented by legal subjects. The purpose of this study is to analyze sanctions against corporate crimes in terms of the Limited Liability Company law and analyze the implementation of law enforcement against corporate crimes in terms of the Limited Liability Company Law. This writing approach uses a normative juridical approach that emphasizes research on existing and applicable laws and regulations. The purpose of the research shows that corporate crime is a crime that is prohibited in the provisions of the legislation. The corporate crime must be the focus of serious attention so that the community does not become a victim in the corporate development process itself. Several countries have determined several models of corporate-related crimes. From the point of view of law enforcement, thinking about the interests of victims of crime in the corporate sector must not only be seen in the framework of conventional and non-conventional crimes, but also illegal abuses of power (economic and public). Related to corporate crime, a structured and complete, and critical understanding is needed for the situation in the development of a corporate action crime. Of course, this is directed so that the consequences of the corporation can be held legally responsible.
\end{abstract}

Keywords: Legal Sanctions; Corporations; Limited Liability Company Law

\section{Introduction}

\subsection{Background of the Study}

Limited Liability Companies or PTs can further develop themselves compared to other Business Entities, especially those that are not in the form of a Legal Entity in carrying out their role as economic actors.[1] A limited company as a contributor to national economic development requires a systematic and obvious legal basis to further enhance national development made as a joint effort based on the principle of kinship, while still bringing up the principles of justice in business. A limited liability company is a legal entity established based on an agreement to conduct business activities with authorized capital that is entirely 
divided into shares and fulfills the requirements stipulated by the law and its implementing regulations. The business activities of the company must be following the aims and objectives of the establishment of the company, and not conflict with the laws and regulations, public order, and/or decency.

The establishment of a company has a purpose, where the intended purpose is realized by human nature as a legal subject, with the ability to be independently responsible on behalf of the corporation. On the other hand, corporations have a negative side, in which the negative side is manifested, among other things, in behaviors that can damage the balance of the ecosystem and social order. These negative actions can be in the form of pollution, depletion (limited natural resources), unfair business competition, tax manipulation, exploitation of workers, issuing products that are harmful to users, and fraud against consumers resulting from crimes committed by corporations.

The establishment of a company has a purpose, where the intended purpose is realized by human nature as a legal subject, with the ability to be independently responsible on behalf of the corporation. On the other hand, corporations have a negative side, in which the negative side is manifested, among other things, in behaviors that can damage the balance of the ecosystem and social order. These negative actions can be in the form of pollution, depletion (limited natural resources), unfair business competition, tax manipulation, exploitation of workers, issuing products that are harmful to users, and fraud against consumers resulting from crimes committed by corporations. [2]

Several disastrous scandals in the corporate world as a result of the unscrupulous actions of various corporations have occurred world. These cases cover various fields. Among other things are in the form of engineering cases of buying and selling shares in the capital market, cases of factory explosions as a result of negligence to take security measures by managers, cases of worker accidents in factories and other companies, cases of accounting manipulation, cases of theft of money, corruption, cases of environmental pollution, passenger bus accident cases, train accidents cases, airplane accidents cases, ship accidents cases, and various other cases. Some cases, according to Phil Matera in his writings, 17 corporate crimes that occurred in 2015, were in the form (quoted in the original written form): 1. Deceptive Practices, 2. Chetingen Depositors, 3. Overcharging Customers, 4. Food Contamination, 5. Adulterated Medication, 6. Illegal Marketing, 7. Failure to Report Safety Defects, 8. Workplace Hazards, 9. Sanctions Violation.[3]

Based on this problem, the researcher is interested in bringing up in a research title "APPLICATION OF LEGAL SANCTIONS AGAINST CORPORATE CRIMES REVIEWING FROM THE LIMITED COMPANY LAW." Our enthusiasm is that problems in the field of corporate crime can be anticipated, and can provide proposed solutions so that improvements can be accommodated.

\subsection{Research Problem}

Based on the identification of the problem, the research questions are as follows:

1. How is criminal liability for corporate crimes in terms of the Limited Liability Company Law?

2. What is the ideal concept of law enforcement against corporate crimes in terms of the Limited Liability Company Law?

\subsection{Research Purposes}


Based on the background of the problem above, the problem is formulated as follows:

1. To analyze and to find out the sanctions for corporate crimes in terms of the Limited Liability Company Law.

2. To find out and analyze the ideal concept of law enforcement against corporate crime in terms of the Limited Liability Company Law.

\subsection{Objectives of the Study}

The usefulness of this research consists of theoretical uses and practical uses as follows:

\section{a) Theoretical Uses}

This paper concludes that it contributes to increasing understanding of legal concepts, especially in business law in terms of the application of sanctions related to corporate crimes, and can be used as input in the development of business law, especially concerning corporate actions.

\section{b) Practical Uses}

This writing is expected to be the basis of consideration for policymakers in making decisions concerning corporate responsibility, in solving the same problems, and making sources of information for the community so that they become lessons in people's social life and input for further researchers who are relevant or related to scientific work in this law.

\section{Method of the Study}

The method in this research serves to explain how the data is collected and how the data is analyzed, and how the results of the analysis will be written down. According to Soetandyo Wignjosoebroto in legal research, which is essentially scientific research, in a literal sense, method means "way". [4] While research is a term in Indonesian that is used as a translation of what in English is called research. Perhaps, it would be more appropriate if the term research is translated as "investigation," even though the term is known as the police term to replace the Dutch word "reserse" (which in turn comes from the French word "rechercher" which also means to search). [5] Thus the method in this research is using normative juridical.

This paper with the title "Implementation of the Corporation Law". Using normative research, the following approaches can be used: Legislative Approach, Case Approach, conceptual approach, philosophical approach. The sources of legal materials used in this research are primary legal materials, secondary legal materials, and tertiary legal materials, analysis of materials the law used is qualitative.

\section{Discussion}

3.1 Criminal Law Liability Against Corporate Crime Judging from the Limited Liability Company Law 
In criminal liability, the burden of responsibility is borne by the perpetrators of criminal offenses related to the basis for imposing criminal sanctions. A person will have the nature of criminal liability if a thing or act committed by him is against the law, but a person can lose the nature of responsibility if an element is found in him that causes the loss of one's ability to be responsible.

The application of sanctions for corporations from the point of view of victims, thinking about the interests of victims of crime in the corporate sector must not only be seen in the framework of conventional and non-conventional crimes but also of illegal abuses of power (economic and public). So broad are the dimensions that can be covered by white-collar crime so that efforts to overcome them cannot simply be done by applying the provisions of existing criminal legislation, but it is necessary to have a comprehensive and critical understanding of various conditions that include the phenomenon of corporate crime.

Thus, in general, the application of legal sanctions for corporations can be interpreted as an act of applying legal instruments to impose legal sanctions to ensure compliance with the stipulated provisions. The ultimate goal of implementing sanctions in compliance with applicable laws. Compliance is a condition for achieving and maintaining the provisions of corporate law, both those that apply in general and those that apply individually. So the application of legal sanctions for corporations includes compliance actions, namely administrative actions (administrative sanctions), and judicial actions include civil lawsuits (compensation and environmental restoration costs) and criminal charges (criminal sanctions).

Based on some of the views above, it is clear that the application of sanctions against corporate crimes when viewed from the Corporation Law, civil law sanctions should be established as long as there is a potential loss from corporate actions, criminal law science has accepted the teachings about corporations as legal subjects' criminal liability that can be held accountable. So, it is clear that with the inclusion of corporations as legal subjects, corporations can be held legally responsible, especially civil ones.

\subsection{Konsep Ideal Penegakan Hukum Terhadap Kejahatan Korporasi Ditinjau Dari Undang-Undang Perseroan Terbatas.}

The Limited Liability Company Law has several weaknesses in its formulation. There are no acts that qualify as corporate crimes, both civil and criminal, making it difficult to measure or determine that a crime has occurred that has caused losses and criminal acts. As an example of an action that results in exceeding the quality standards of water, air, and environmental damage standards, the punishment is criminal. However, the benchmarks or criteria for determining whether the quality standards for environmental damage have been exceeded are not fully regulated in subsequent regulations or implementing regulations as well as losses due to environmental damage caused by corporations. This issue has an impact on the implementation process of the law enforcement because, in terms of the formulation of threatening the act with a crime, law enforcers process violators with criminal law rules turns out that after the case is running, law enforcement stagnates (stagnation), because investigators find it difficult to prove the elements of the offense formulated in law.

The lack of clarity in legislative policies will automatically have an impact on law enforcement in the field. Not a few investigators and PPNS find it difficult to resolve cases of air, water, and seawater pollution due to the absence of rules that determine standard criteria regarding air, ambient water, and seawater pollution as well as environmental damage caused by corporations. If in terms of legal norms has caused debate, it will become a problem that has an impact on the unresolved law enforcement caused by the Corporation. So far, this 
condition often occurs, so that investigators need to consider the direction of law enforcement, whether it will be brought to the criminal, civil or administrative realm because of the dualistic nature of the rules.

Until now, the case of corporate crime has not been maximally regulated in the Limited Liability Company Law, so that it only emphasizes the punishment of Indonesian citizens who are suspected of committing corporate crimes, which have created legal uncertainty and a sense of injustice for the community. Therefore, it is necessary to change the law that is stricter against corporate crime. When examined in terms of the philosophy of law enforcement ideals, according to Gustav Redbruch, there are 3 (three) basic legal ideas that must be achieved in law enforcement. Redbruch stated that there are difficulties in realizing the three objectives of the law simultaneously. However, Redbruch teaches that law enforcement must use the principle of priority where the main priority falls on justice, then benefits, and finally legal certainty. Mardjono Reksodiputro stated that the purpose of law enforcement is not only to use the principle of priority but also needs to be case-based. The author himself places more emphasis on the fact that he sees the principle of priority on a case-by-case basis, meaning that in other words, it must be seen on a case-by-case basis.

Law enforcers must prioritize the principles of justice, expediency, and then legal certainty, considering that corporate crimes are crimes that are committed not out of necessity (crime not by need) but because of business interests (crime by business interests). Therefore, it is necessary to adjust the legal sanctions that will be applied. Judges need to consider aspects of justice, and the benefits of paying fines will be fairer and more beneficial for the community and the environment if the decision handed down takes into account the losses incurred.

\section{Closing}

\subsection{Conclusion}

1. Alleged actions of crimes committed by subjects of corporate law can be held criminally responsible following criminal provisions, in essence, an agency or association that can have rights and act like a human being, and has its wealth, can be sued and sued before a judge.

2. From the point of view of law enforcement, the point of view of the sense of justice for victims of crime in the corporate sector must be viewed as a whole, namely conventional and non-conventional crimes, but also illegal abuses of power (economic and public).

\subsection{Suggestion}

1. Regarding the application of sanctions against corporate law enforcement, there should be special rules regarding the Cooperative Crime Eradication Law so that it can create a sense of justice for victims and perpetrators of corporate crime as legal subjects that can be prosecuted so that the public, in general, is not harmed.

2. It is better for law enforcers who examine corporate crime cases to have a sense of renewal who are willing to create new legal views in filling the legal vacuum regarding the imposition of legal responsibility on a corporation. 


\section{References}

[1] Hartono, S. R. (n.d.). Makalah Seminar dan Lokakarya. Pembangunan Hukum Nasional VIII.

[2] Mas Achmad Santosa, "Esensi Penerapan Asas Tanggung Jawab Mutlak (Strict Liability) dalam Konteks Penegakan Hukum Lingkungan di Indonesia"dalam Jurnal Hukum Lingkungan Tahun II No. 1/1995 (Jakarta: Indonesian Center for Environmental Law, 1995)

[3] Hanafi, KejahatanKorporasi (Yogyakarta: Fakultas Hukum Universitas Islam Indonesia, 2000

[4] Satjipto Rahardjo, IlmuHukum (Bandung: PT. Citra Aditya Bakti), 2000

[5] Soedjono Dirdjosisworo, "HukumPidana Indonesia dan GelagatKriminalitas Masyarakat Pascaindustri”, ( Bandung: FH UNPAR,) 1991

[6] Sutan Rehmi Sjahdaeni, TindakPidanaKorporasi dan Seluk-Beluknya, Kencana, Depok, 2017

[7] Sulistyo wati Irianto\&Shidarta, MetodePenelitianHukumKonstelasi dan Refleksi, (Jakarta: Yayasan PustakaObor Indonesia,) 2009

[8] Rahmat Febrianto, Karakteristik perusahaan yang mengganti Auditor sebagai dampak dari kasus enron dan keputusan Menteri Keuangan Indonesia,( Yogyakarta: program Doktor, Fakultas Ekonomi dan Bisnis Universitas Gajah Mada), 2009

[9] Muladi dan DwidjaPriyatno, PertanggungjawabPidanaKorporasi, Prenada Media Group, Jakarta, 2010

[10] J.E. Sahetapy, KejahatanKorporasi, RefikaAditama, Bandung, 2002

[11] Kristian, Urgensi Pertanggungjawaban PidanaKorporasi, Jurnal Hukum dan Pembangunan, Tahun ke-44 No. 4 Oktober-Desember 2013

[12] Mardjono Reksodiputro, Kriminologi dan SistemPeradilanPidana (Jakarta: Pusat Pelayanan Keadilan dan Pengabdian Hukum Universitas Indonesia,) 1994.

[13] Sudarto, Suatu Dilemma dalam Pembaharuan SistimPidana Indonesia, Pidato Pengukuhanjabatan Guru besar dalam Hukum Pidana pada Universitas Diponegoro (Semarang: Undip), 1974 